\title{
Filling Stations and Their Effects on Groundwater Quality in Ilorin Metropolis
}

\author{
Oluwaseun Emmanuel Odipe ${ }^{1, *}$, Henry Olawale Sawyerr ${ }^{1}$, Solomon Olayinka Adewoye ${ }^{2}$ \\ ${ }^{1}$ Department of Environmental Health Sciences, School of Allied Health and Environmental Science, College of Pure and Applied Science, \\ Kwara State University, Malete, Nigeria \\ ${ }^{2}$ Department of Pure and Applied Biology, Faculty of Pure and Applied Science, Ladoke Akintola University of Technology, Ogbomosho, \\ Nigeria
}

Email address:

odipe@yahoo.com (O. E. Odipe), henry.sawyerr@kwasu.edu.ng (H. O Sawyerr), soadewoye@lautech.edu.ng (S. O Adewoye)

${ }^{*}$ Corresponding author

\section{To cite this article:}

Oluwaseun Emmanuel Odipe, Henry Olawale Sawyerr, Solomon Olayinka Adewoye. Filling Stations and Their Effects on Groundwater Quality in Ilorin Metropolis. International Journal of Environmental Protection and Policy. Vol. 8, No. 1, 2020, pp. 11-21.

doi: $10.11648 /$ j.ijepp.20200801.12

Received: January 29, 2020; Accepted: February 11, 2020; Published: February 19, 2020

\begin{abstract}
The study aimed to assess groundwater quality of hand-dug wells at close proximities to filling stations in Ilorin metropolis. The study involved analyses for physicochemical and heavy metal constituents of the water samples. The sample size was purposively selected across the three (3) local government areas of Ilorin, twenty-six (26) accessible functioning stations above 15 years of establishment in the metropolis with hand-dug wells within or around its premises were chosen. Samples were analyzed for physicochemical parameters such as Temperature, Turbidity, Conductivity, Total Dissolved Solid, Total Hardness, Calcium, Magnesium, Chloride, Fluoride, Ammonia, Nitrate, Nitrite, and Heavy metals like Lead, Chromium, Cadmium, Iron, Zinc, Copper, Nickel using standard methods. Results were compared with the Nigerian Standard for Drinking Water Quality which revealed anomaly in concentration of some parameters such as Turbidity, Conductivity, Total Dissolved solids, Total Hardness, Lead, Cadmium, Chromium, and Nickel at some stations. The results from the combined physicochemical and heavy metal analyses of the water samples indicated activities of the filling stations within the area may have polluted groundwater in the environment posing an aesthetically unappealing situation and great health risk to consumers of the water resources.
\end{abstract}

Keywords: Groundwater, Filling Stations, Physicochemical, Heavy Metals, Water Quality

\section{Introduction}

Water quality which entails the physical, chemical, and biological properties of naturally occurring water for its designated use can be influenced by natural or anthropogenic activities, causing a deviation from norm hence posing possible health risk to consumers and users of the resource [1]. This is a global concern as over $80 \%$ of diseases and deaths in low - middle income countries are related to bad/low water quality $[2,3]$. Among the numerous sources of pollutants, some of the reported cases include accidental spills of chemicals, improper waste disposal (liquid and solid), pesticides applications, fertilizers application, runoffs from agricultural sites, waste ponds (sewerage and its likes), septic tanks, salt water intrusion, acid mine drainage, leakages of underground storage tanks, pipeline and injection wells etc. $[4,5]$.

In Nigeria, there is a geometric increase in the construction of filling stations at irregular and clustered patterns at close proximities to residential settlements nationwide [6-9]. This unchecked proliferation is an issue of environmental and health concern as there are reports of soil and groundwater pollution by leaking underground tanks from filling stations globally [4, 8, 10-16]. Hence, great risks to human health and the environment are posed by unregulated construction of filling stations in our communities. The study hereby 
assessed the groundwater quality of hand-dug wells at close proximities to filling stations in Ilorin metropolis.

\section{Materials and Methods}

\subsection{Area Description and Sample Size Determination}

The study was carried out across Ilorin Metropolis, which is the urban centre of the ancient Ilorin emirate (the present day capital town) of Kwara State, North-Central, Nigeria. It lies within coordinates of Latitude $8^{\circ} 30^{\prime} \mathrm{N}$ and Longitude $4^{\circ}$ $30^{\prime} \mathrm{E}$ respectively and it covers an approximated area of 180 sqkm within $765 \mathrm{sqkm}$ of the three (3) local government areas in Ilorin town. (Figure 1)

The sample size for the present study was purposively selected based on some criteria, a multi-step approach was used to select the final size of the filling station sampled in the study, at the time of study, a total of 297 stations were identified within the Ilorin town across all local governments (Ilorin West, East and South), where 199 stations were within the metropolis, and 166 were functioning [9]. Of the functioning stations, based on the age inclusion criteria, a total of 68 stations were found to be above 15 years of establishment and finally 29 filling stations had wells within its premises or at close proximity. A total of 26 stations were eventually sampled as some challenges were faced in assessing water samples at 3 stations. The limitation of the study to stations above 15 years was guided by a finding that most Chinese made oil quality single tank (like the one's majorly used here in Nigeria) has an average life expectancy of 8 years [17], and hand-dug wells are the most available source of potable water in the metropolis (Figure 2).

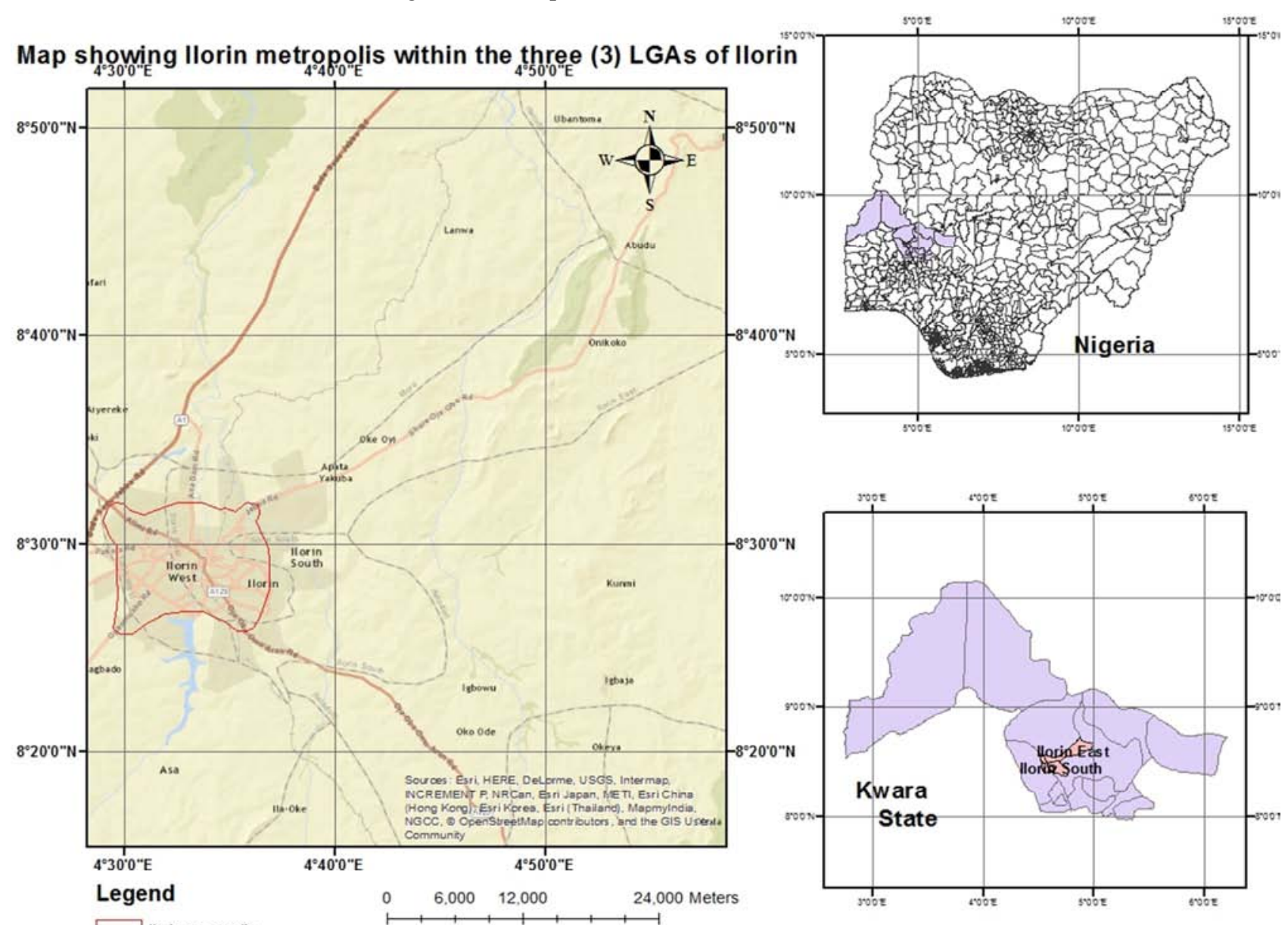

Figure 1. Showing the map of Ilorin metropolis within the three (3) local government areas of Ilorin town.

\subsection{Water Sample Collection and Analysis}

Groundwater samples were collected from hand dug wells within and around the premises of 26 filling stations that were above 15years of age and functioning. The distance of the well (sample points) to the underground storage tanks were measured. The method of sampling was the grab/spot sampling. The water samples were collected into $100 \mathrm{ml}$ sample bottles, which were labelled at the point of collection and transported to the laboratory for analysis immediately. Duplicate samples were also taken from the sampled wells for precision.

While collecting water samples, some physical measurements were taken at the sample location to give more scientific details of the surrounding environment before further analysis were carried out in the laboratory.

Samples were analysed for different physico-chemical 
parameters such as, temperature, turbidity, $\mathrm{pH}$, electrical conductivity (EC), total dissolved solids (TDS), total hardness $(\mathrm{TH})$, calcium $\left(\mathrm{Ca}^{2+}\right)$, magnesium $\left(\mathrm{Mg}^{2+}\right)$, chloride (Cl-), Fluoride (F-), Ammonia $\left(\mathrm{NH}_{3}\right)$, Nitrate $\left(\mathrm{NO}_{3}{ }^{-}\right)$, and Nitrite $\left(\mathrm{NO}_{2}\right)$ following described standard procedures [31].

Heavy metals were measured using the atomic absorption spectrophotometer. This method as described by the
Association of Official Analytical Chemist (2005) [32] was used for mineral analysis. The heavy metals measured were Lead $(\mathrm{Pb})$, Cadmium $(\mathrm{Cd})$, Copper $(\mathrm{Cu})$, Chromium $(\mathrm{Cr})$, Nickel (Ni), Zinc (Zn) and Iron (Fe).

The quality of groundwater was later compared to the Nigerian drinking water quality standards [18] desirable limit for the measured parameters.

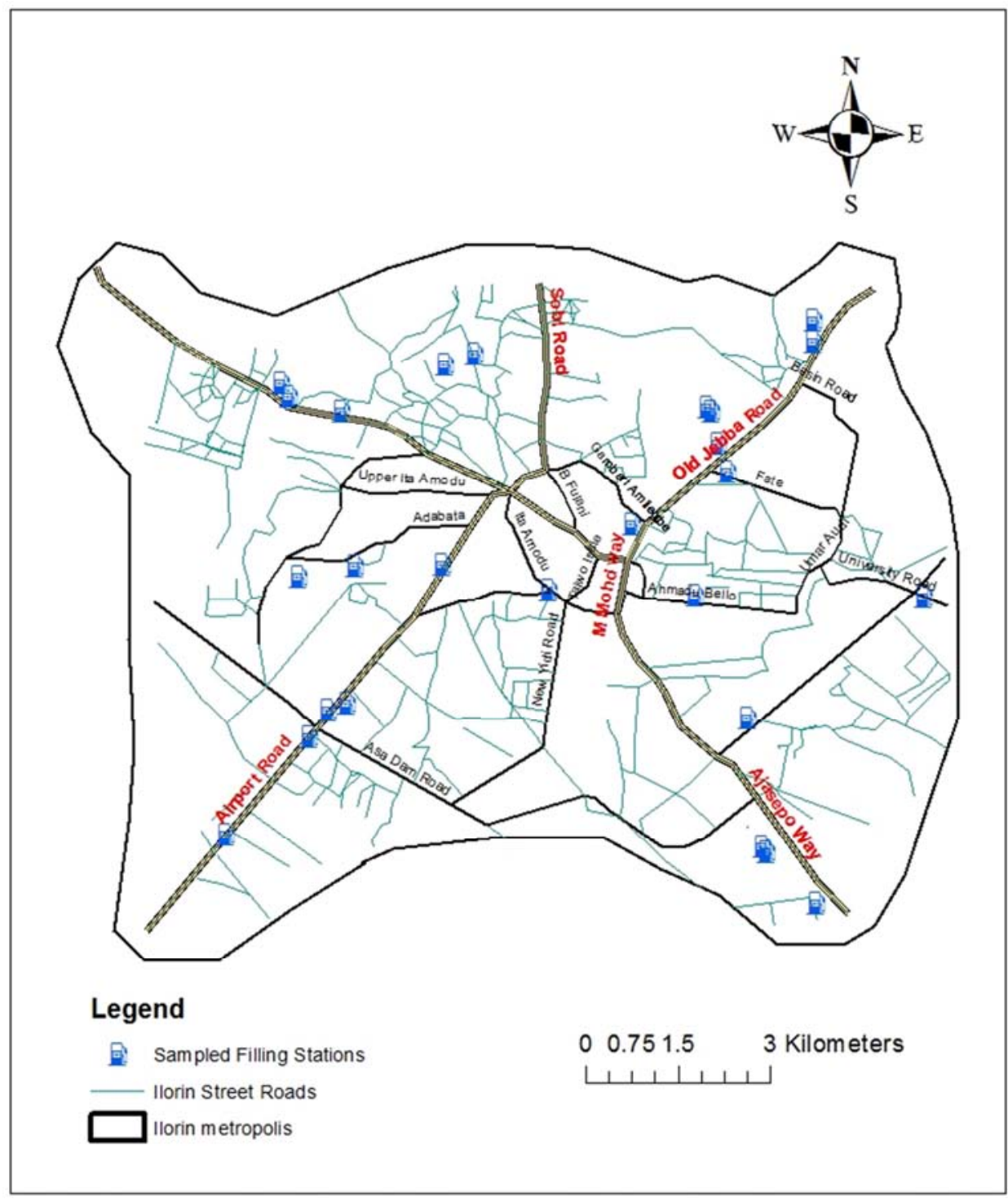

Figure 2. The Spatial Distribution of the Selected Sample Stations.

\section{Results}

The study revealed that $23(88.5 \%)$ of the 26 water sources were located within the filling stations and a total of 17 $(65.4 \%)$ were at a distance of less than $30 \mathrm{~m}$ from the Underground storage tanks in these stations.

\subsection{Physicochemical Parameters}

Table 1 presents the profiles of the physicochemical parameters at each station. After which parameters with significant values indicating possible anomaly from the country's standards for drinking water were represented in
Figures 3 - 6 showing the variations for Turbidity, Conductivity, Total Dissolved solids, and Total Hardness.

\subsection{Heavy Metals Concentration}

Table 2 presents the results of the heavy metal concentrations at the sampled stations. After which parameters with significant values indicating possible anomaly from the country's standards for drinking water are represented in Figures 7 - 10 showing the variations of concentrations in Lead $(\mathrm{Pb})$, Cadmium $(\mathrm{Cd})$, Chromium $(\mathrm{Cr})$, and Nickel (Ni). 
Table 1. Mean values of Physico-chemical characteristics of Water Samples from Hand Dug wells around Filling Stations.

\begin{tabular}{|c|c|c|c|c|c|c|c|c|c|c|c|c|c|}
\hline $\begin{array}{l}\text { SAMPLED } \\
\text { STATIONS } \\
\end{array}$ & $\mathbf{T}\left({ }^{\circ} \mathbf{C}\right)$ & $\begin{array}{l}\text { TBD. } \\
\text { (NTU) }\end{array}$ & $\mathbf{p H}$ & $\begin{array}{l}\text { CON. } \\
(\mu \mathrm{S} / \mathrm{cm})\end{array}$ & $\begin{array}{l}\text { TDS } \\
(\mathrm{mg} / \mathrm{l})\end{array}$ & $\begin{array}{l}\mathrm{TH} \\
(\mathrm{mg} / \mathrm{l})\end{array}$ & $\begin{array}{l}\mathrm{Ca} \\
(\mathrm{mg} / \mathrm{l})\end{array}$ & $\begin{array}{l}\mathrm{Mg} \\
(\mathrm{mg} / \mathrm{l})\end{array}$ & $\begin{array}{l}\mathrm{Cl}^{-} \\
(\mathrm{mg} / \mathrm{l})\end{array}$ & $\begin{array}{l}F^{-} \\
(\mathrm{mg} / \mathrm{l})\end{array}$ & $\begin{array}{l}\mathrm{NH}_{3} \\
(\mathrm{mg} / \mathrm{l})\end{array}$ & $\begin{array}{l}\mathrm{NO}_{3} \\
(\mathrm{mg} / \mathrm{l})\end{array}$ & $\begin{array}{l}\mathrm{NO}_{2} \\
(\mathrm{mg} / \mathrm{l}) \\
\end{array}$ \\
\hline A & 26.9 & 5.5 & 7.1 & 975 & 558 & 375 & 53 & 40 & 263 & 0.16 & 0.11 & 8.12 & 0.11 \\
\hline B & 27.0 & 5.4 & 7.2 & 970 & 553 & 370 & 52 & 45 & 256 & 0.13 & 0.11 & 8.11 & 0.12 \\
\hline $\mathrm{C}$ & 27.0 & 5.5 & 7.1 & 965 & 540 & 355 & 50 & 42 & 260 & 0.18 & 0.12 & 8.11 & 0.11 \\
\hline D & 27.3 & 5.4 & 7.1 & 980 & 565 & 384 & 54 & 42 & 265 & 0.18 & 0.12 & 8.11 & 0.12 \\
\hline E & 27.1 & 5.4 & 7.1 & 960 & 538 & 355 & 52 & 44 & 260 & 0.17 & 0.11 & 8.12 & 0.12 \\
\hline $\mathrm{F}$ & 26.6 & 2.1 & 7.1 & 733 & 515 & 220 & 54 & 34 & 262 & 0.18 & 0.14 & 4.10 & 0.10 \\
\hline G & 27.3 & 8.2 & 7.3 & 215 & 294 & 168 & 20 & 116 & 155 & 0.12 & 0.20 & 10.14 & 0.30 \\
\hline $\mathrm{H}$ & 27.5 & 8.4 & 7.3 & 218 & 297 & 165 & 20 & 119 & 158 & 0.11 & 0.25 & 10.15 & 0.30 \\
\hline I & 26.8 & 2.2 & 7.0 & 748 & 520 & 225 & 54 & 35 & 253 & 0.18 & 0.14 & 4.10 & 0.10 \\
\hline $\mathrm{J}$ & 27.8 & 9.0 & 7.4 & 205 & 98 & 154 & 63 & 20 & 14 & 0.06 & 0.25 & 10.20 & 0.30 \\
\hline $\mathrm{K}$ & 27.3 & 5.6 & 7.2 & 950 & 555 & 350 & 55 & 40 & 255 & 0.18 & 0.25 & 8.15 & 0.16 \\
\hline $\mathrm{L}$ & 27.2 & 5.6 & 7.2 & 960 & 240 & 144 & 85 & 40 & 40 & 0.16 & 0.18 & 8.14 & 0.13 \\
\hline M & 27.7 & 8.8 & 7.4 & 200 & 295 & 160 & 28 & 12 & 150 & 0.14 & 0.21 & 10.17 & 0.31 \\
\hline $\mathrm{N}$ & 27.3 & 5.8 & 7.3 & 955 & 564 & 360 & 57 & 38 & 260 & 0.16 & 0.11 & 8.15 & 0.15 \\
\hline $\mathrm{O}$ & 27.9 & 9.0 & 7.4 & 202 & 94.3 & 161 & 60 & 18 & 12 & 0.05 & 0.20 & 10.17 & 0.30 \\
\hline $\mathrm{P}$ & 26.8 & 2.8 & 7.3 & 730 & 508 & 215 & 57 & 32 & 251 & 0.34 & 0.14 & 4.12 & 0.12 \\
\hline Q & 27.0 & 2.9 & 7.2 & 741 & 508 & 220 & 53 & 32 & 252 & 0.38 & 0.14 & 4.12 & 0.11 \\
\hline $\mathrm{R}$ & 27.3 & 5.7 & 7.3 & 950 & 553 & 350 & 55 & 42 & 254 & 0.14 & 0.13 & 8.14 & 0.15 \\
\hline S & 27.2 & 5.8 & 7.1 & 960 & 570 & 375 & 59 & 40 & 263 & 0.17 & 0.18 & 8.14 & 0.15 \\
\hline $\mathrm{T}$ & 27.0 & 2.8 & 7.2 & 734 & 215 & 142 & 15 & 39 & 32 & 0.12 & 0.14 & 4.12 & 0.12 \\
\hline $\mathrm{U}$ & 27.3 & 5.8 & 7.1 & $946^{\circ}$ & 564 & 345 & 54 & 41 & 251 & 0.17 & 0.11 & 8.14 & 0.14 \\
\hline V & 27.2 & 5.8 & 7.3 & 960 & 340 & 141 & 53 & 46 & 38 & 0.15 & 0.11 & 8.15 & 0.15 \\
\hline W & 27.3 & 5.8 & 7.2 & 946 & 260 & 133 & 52 & 48 & 42 & 0.15 & 0.10 & 8.14 & 0.13 \\
\hline X & 27.8 & 8.9 & 7.5 & 205 & 298 & 163 & 29 & 14 & 155 & 0.13 & 0.27 & 10.2 & 0.32 \\
\hline Y & 27.3 & 5.7 & 7.1 & 960 & 253 & 130 & 42 & 47 & 40 & 0.14 & 0.24 & 8.15 & 0.15 \\
\hline Z & 27.3 & 5.9 & 7.2 & 950 & 268 & 138 & 64 & 49 & 42 & 0.15 & 0.13 & 8.14 & 0.15 \\
\hline NSDQW [18] & Ambient & 5 & $6.5-8.5$ & 1000 & 500 & 150 & 75 & 2.0 & 250 & 1.5 & - & 50 & 0.2 \\
\hline
\end{tabular}

N.B: T- Temperature, TBD- Turbidity, CON- Conductivity, TDS- Total Dissolved Solid, TH- Total Hardness, Ca- Calcium, $\mathrm{Mg}^{-} \mathrm{Magnesium}, \mathrm{Cl}^{-}$- Chloride, $\mathrm{F}^{-}$Fluoride, $\mathrm{NH}_{3-}$ Ammonia, $\mathrm{NO}_{3}$ - Nitrate, $\mathrm{NO}_{2}$ - Nitrite, $\mathrm{NSDQW}$ - Nigerian Standard for Drinking Water Quality.

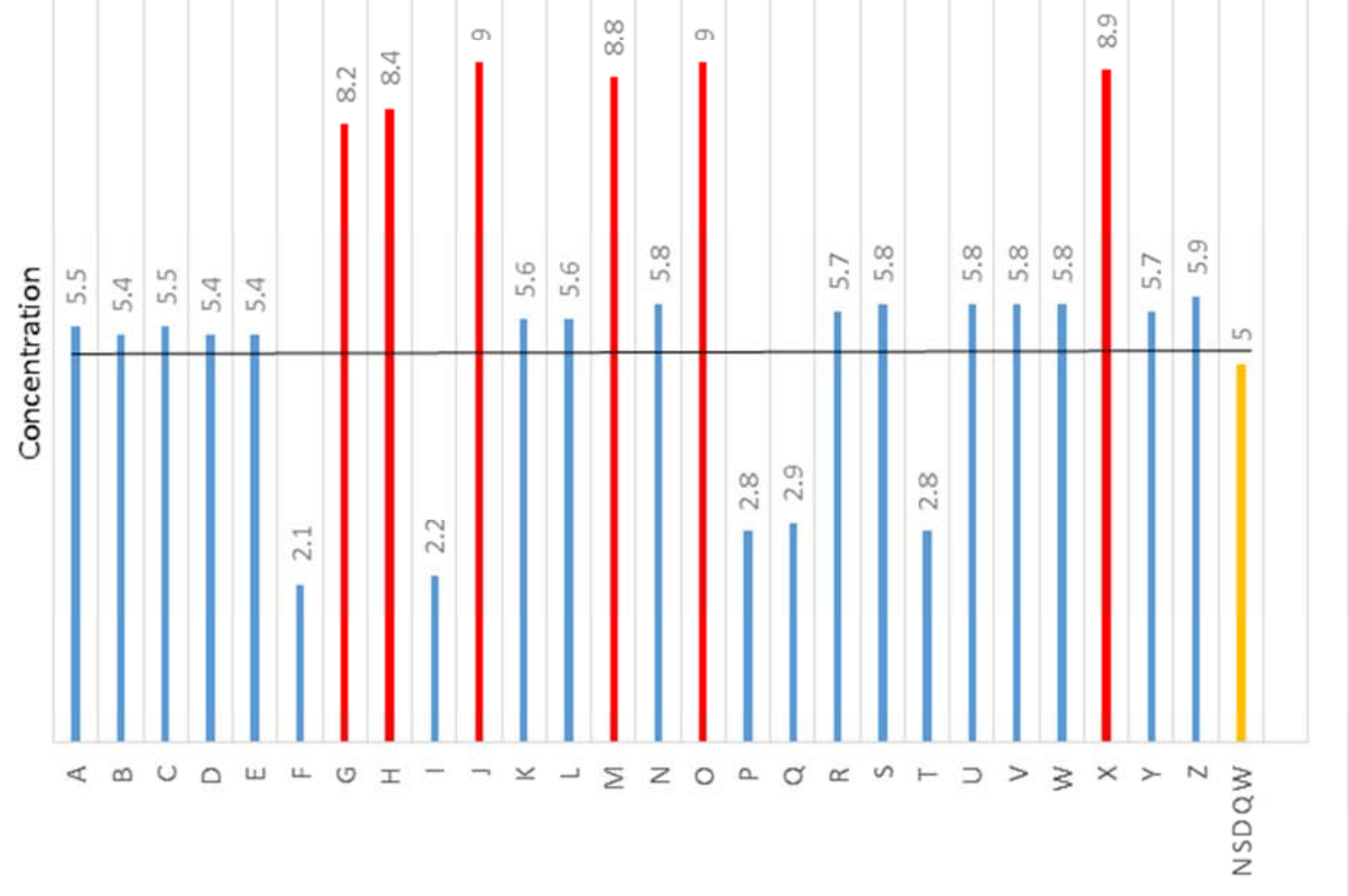

Figure 3. Concentration of turbidity of water samples from sampled stations. 


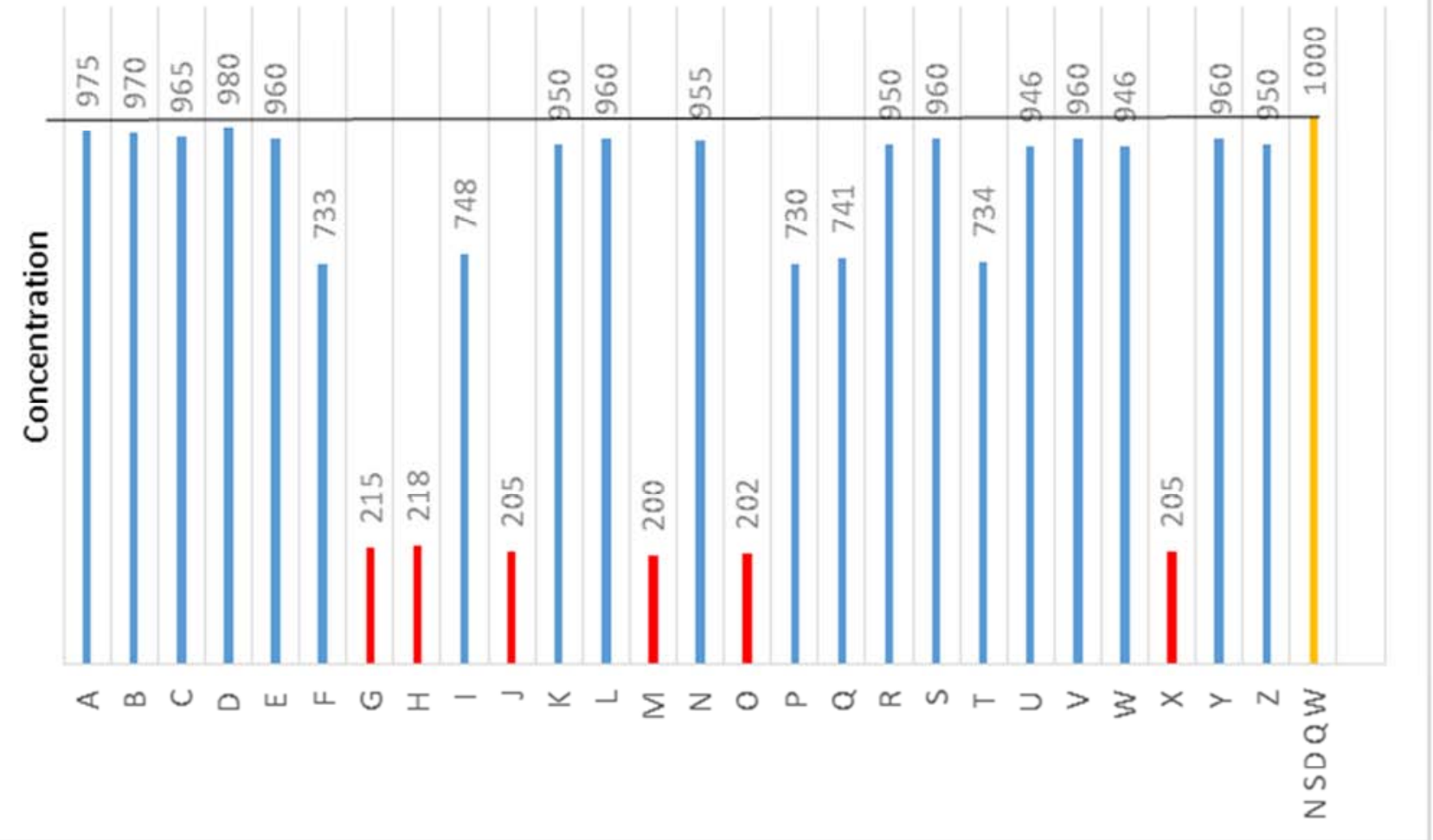

Figure 4. Concentration of hydraulic conductivity of water samples from sampled stations.

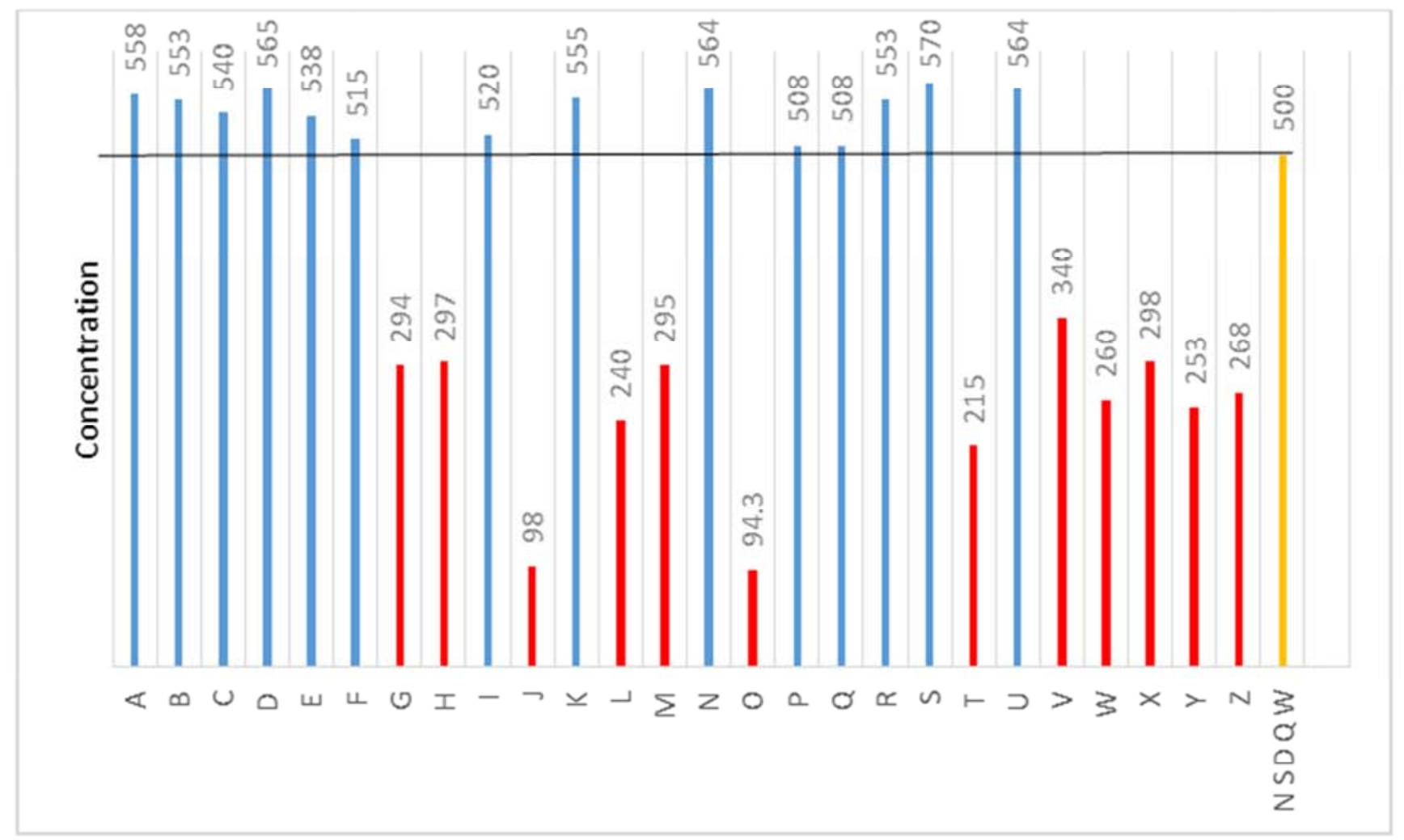

Figure 5. Concentration of total dissolved solids in water samples from sampled stations. 


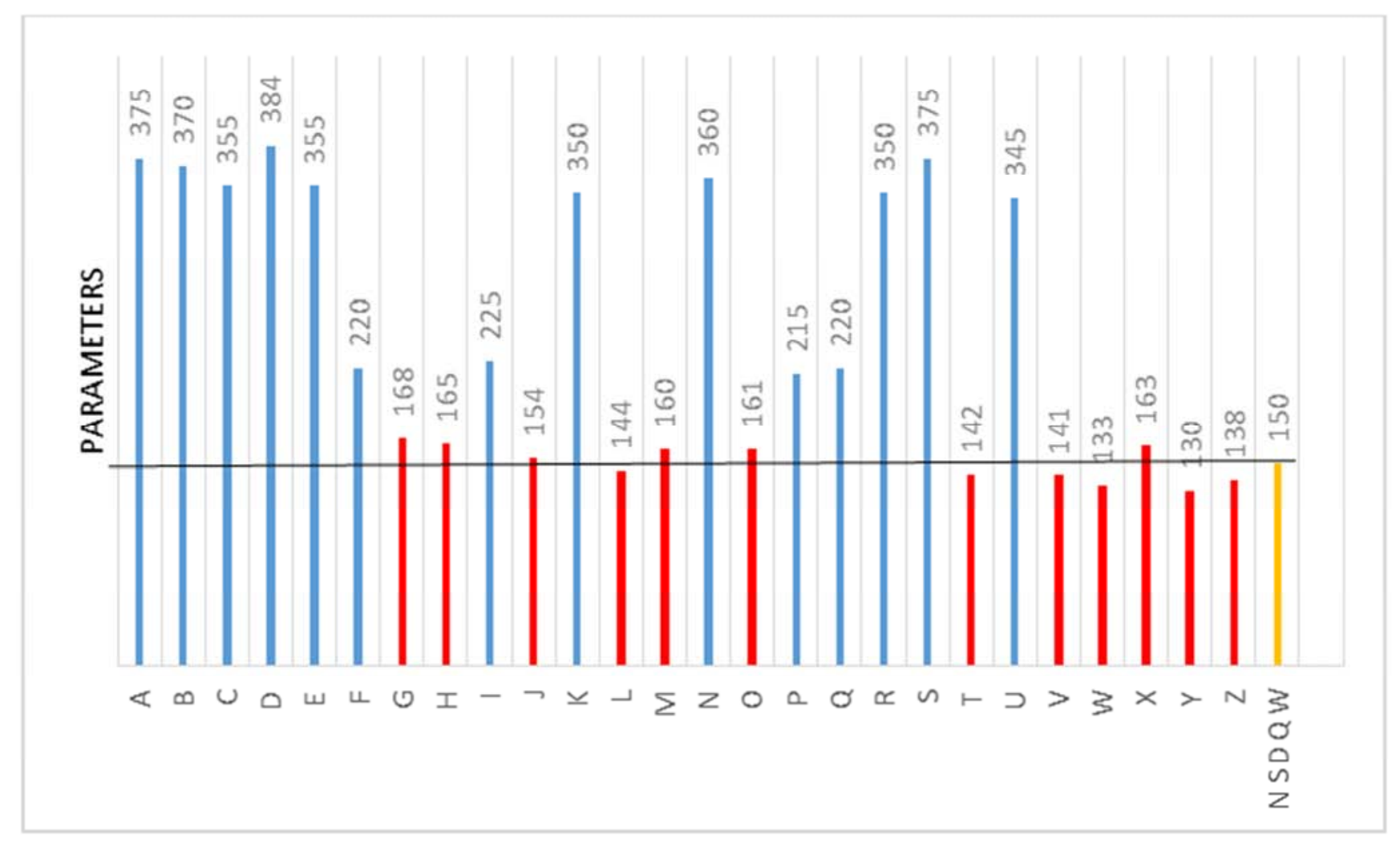

Figure 6. Concentration of total hardness in water samples from sampled stations.

Table 2. Heavy metal concentration of Water Samples.

\begin{tabular}{|c|c|c|c|c|c|c|c|}
\hline SAMPLED STATIONS & $\mathrm{Pb}(\mathrm{mg} / \mathrm{l})$ & $\mathrm{Cd}(\mathrm{mg} / \mathrm{l})$ & $\mathrm{Cu}(\mathrm{mg} / \mathrm{l})$ & $\mathrm{Cr}(\mathrm{mg} / \mathrm{l})$ & $\mathrm{Ni}(\mathrm{mg} / \mathrm{l})$ & $\mathrm{Zn}$ (mg/l) & $\mathrm{Fe}(\mathrm{mg} / \mathrm{l})$ \\
\hline A & 0.01 & N.D & 0.03 & N.D & 0.01 & 0.01 & 0.01 \\
\hline B & 0.02 & N.D & 0.03 & 0.01 & 0.01 & 0.01 & 0.01 \\
\hline $\mathrm{C}$ & 0.04 & 0.01 & 0.02 & N.D & 0.02 & N.D & 0.03 \\
\hline $\mathrm{D}$ & 0.05 & N.D & 0.04 & 0.08 & N.D & N.D & 0.03 \\
\hline $\mathrm{E}$ & N.D & N.D & 0.01 & 0.01 & 0.03 & N.D & 0.03 \\
\hline $\mathrm{F}$ & N.D & N.D & 0.07 & 0.06 & 0.01 & N.D & 0.05 \\
\hline G & N.D & N.D & 0.01 & N.D & 0.01 & N.D & N.D \\
\hline $\mathrm{H}$ & N.D & N.D & N.D & N.D & N.D & N.D & N.D \\
\hline I & N.D & N.D & N.D & 0.05 & N.D & N.D & N.D \\
\hline $\mathrm{J}$ & 0.01 & 0.01 & 0.08 & N.D & 0.03 & N.D & N.D \\
\hline K & 0.01 & N.D & N.D & 0.03 & 0.01 & 0.01 & 0.03 \\
\hline $\mathrm{L}$ & 0.03 & N.D & N.D & 0.03 & N.D & 0.01 & 0.03 \\
\hline M & 0.01 & N.D & N.D & N.D & N.D & N.D & 0.03 \\
\hline $\mathrm{N}$ & 0.01 & 0.01 & 0.08 & 0.03 & N.D & N.D & 0.03 \\
\hline $\mathrm{O}$ & 0.04 & N.D & 0.02 & N.D & N.D & 0.01 & 0.03 \\
\hline $\mathrm{P}$ & N.D & N.D & N.D & 0.01 & N.D & N.D & 0.02 \\
\hline Q & N.D & N.D & 0.03 & N.D & N.D & N.D & 0.02 \\
\hline $\mathrm{R}$ & 0.01 & 0.01 & 0.02 & N.D & N.D & 0.01 & 0.02 \\
\hline $\mathrm{S}$ & 0.03 & 0.01 & 0.04 & N.D & 0.02 & 0.01 & 0.02 \\
\hline $\mathrm{T}$ & N.D & N.D & 0.01 & N.D & 0.01 & 0.01 & 0.05 \\
\hline $\mathrm{U}$ & N.D & N.D & N.D & 0.01 & N.D & N.D & 0.01 \\
\hline V & N.D & N.D & 0.01 & N.D & N.D & N.D & 0.01 \\
\hline W & 0.02 & N.D & N.D & 0.04 & N.D & N.D & 0.07 \\
\hline $\mathrm{X}$ & 0.02 & N.D & N.D & 0.05 & N.D & N.D & 0.01 \\
\hline Y & 0.01 & N.D & N.D & 0.03 & 0.05 & N.D & 0.15 \\
\hline Z & 0.01 & N.D & 0.02 & 0.03 & N.D & N.D & 0.17 \\
\hline NSDQW [18] & 0.01 & 0.003 & 1.00 & 0.05 & 0.02 & 3.00 & 0.30 \\
\hline
\end{tabular}

N.B: Pb- Lead, Cr- Chromium, Cd- Cadmium, Fe- Iron, Zn- Zinc, Cu- Copper, Ni- Nickel, N.D- Not detected, NSDQW - Nigerian Standard for Drinking Water Quality. 


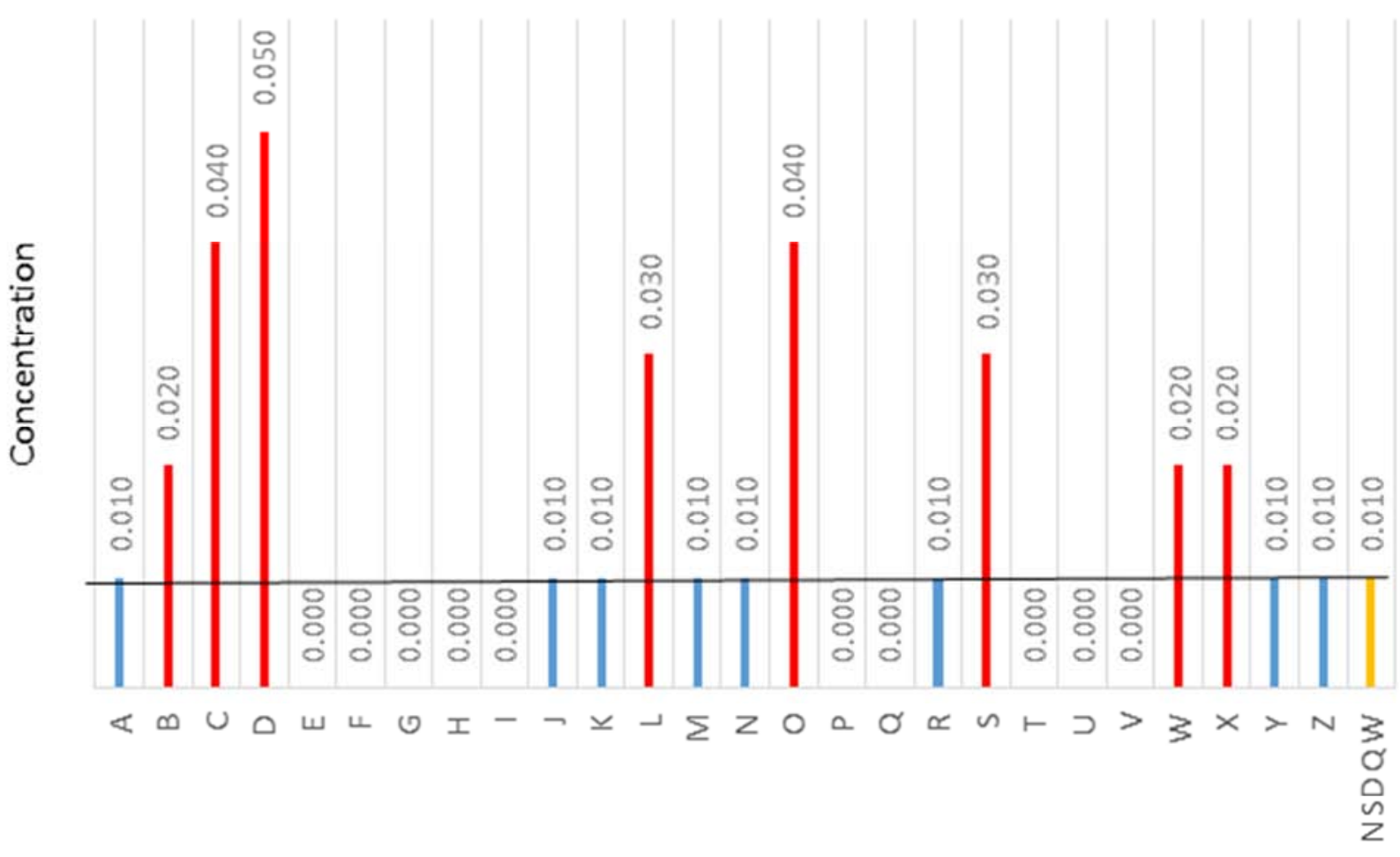

Figure 7. Concentration of lead in water samples from sampled stations.

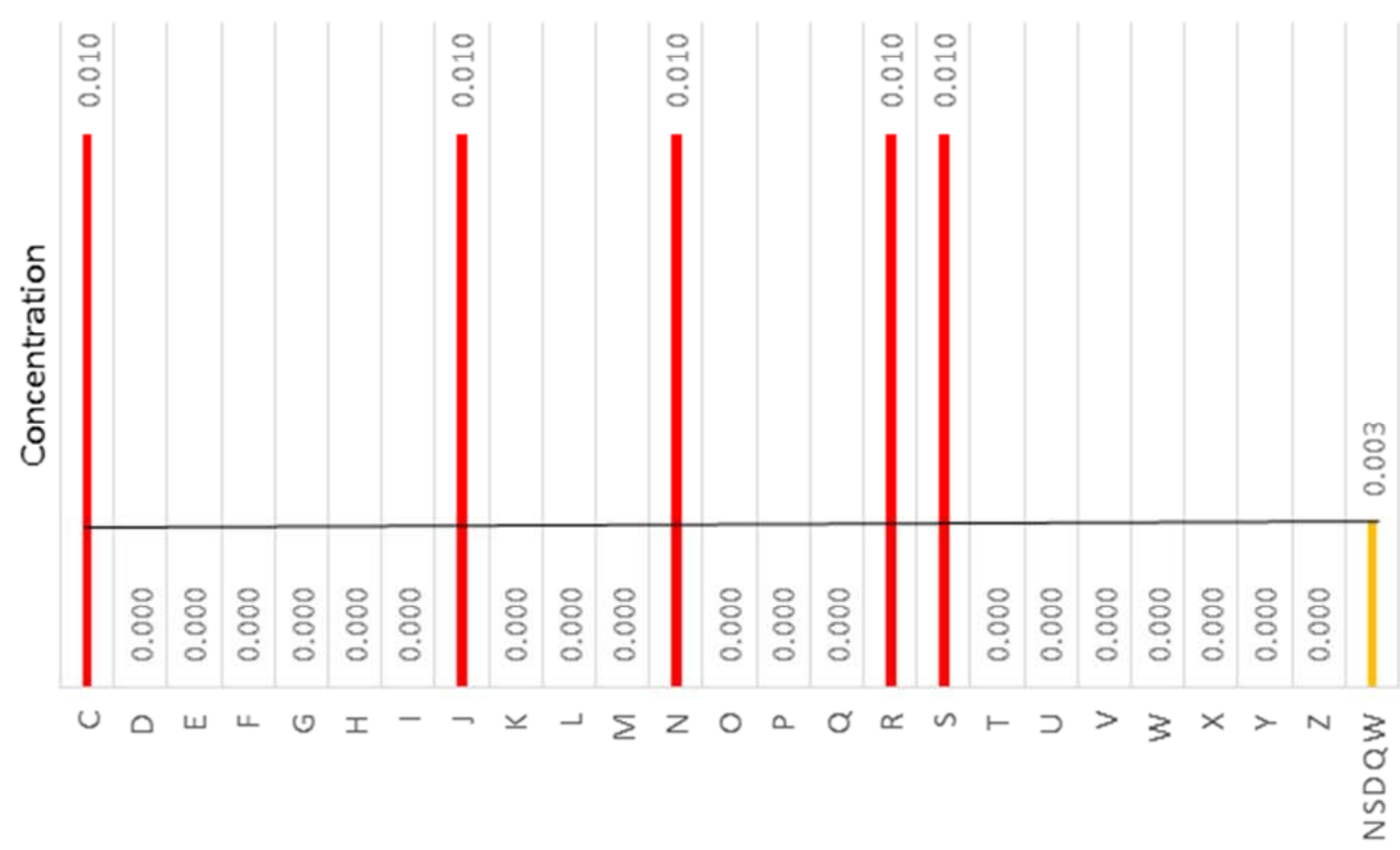

Figure 8. Concentration of cadmium of water samples from sampled stations. 


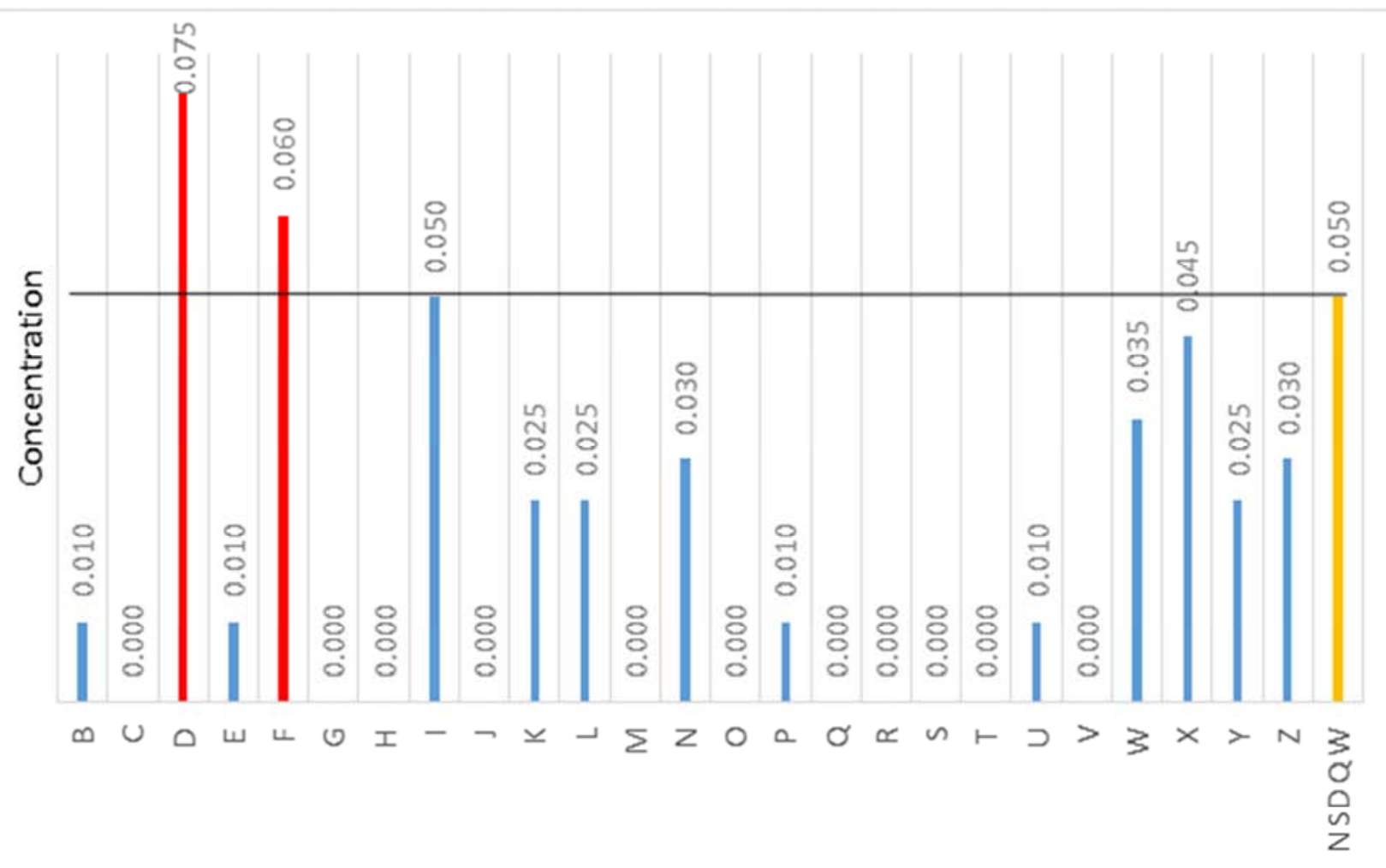

Figure 9. Concentration of chromium in water samples from sampled stations.

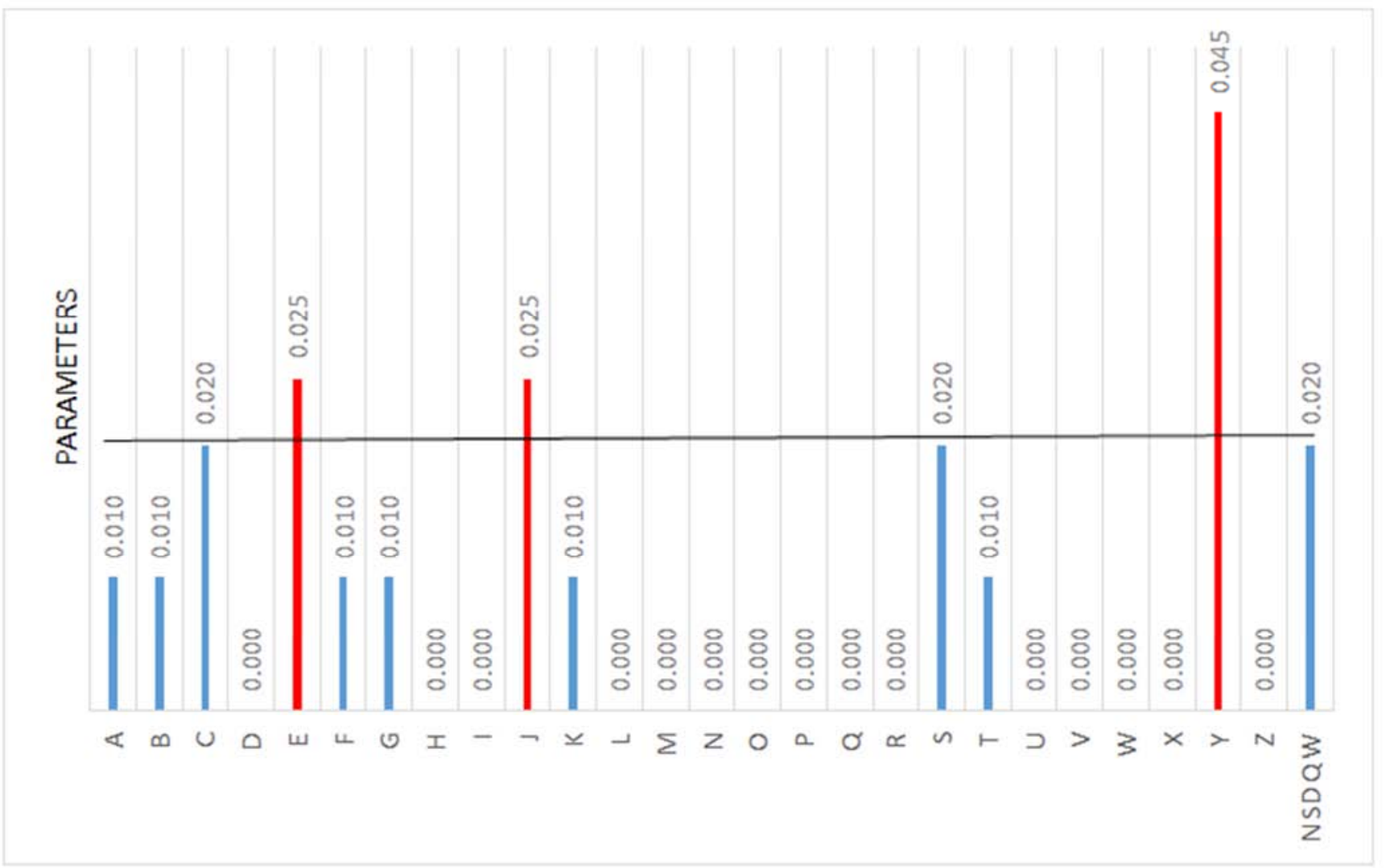

Figure 10. Concentration of nickel in water samples from sampled stations. 


\section{Discussion}

\subsection{Physico-chemical Assessment of Water Samples at Sampled Stations}

The basic hydrographic parameters, the temperature measured across all samples were ambient, while the average turbidity values showed only $19 \%$ of the samples fell within the acceptable threshold value of 5 NTU [18], 58\% were slightly higher than the acceptable standard falling with a range of $5.4-5.9$, while $23 \%$ had values higher than 8.2 (Samples G, H, J, M, O, X). Similar findings were observed in Chen et al., [17] where high turbidity values were recorded indicating possible high concentration of hydrocarbon and other pollutants but this showed that the concentration of ammonia, turbidity and nutrients concentration decreased with time as natural attenuation and organic decomposition took place in the hydrocarbon polluted zones, hence the significant high values in this study might be attributed to the release of pollutants into the environment which brought about the objectionable values.

The conductivity measured in $\mu \mathrm{S} / \mathrm{cm}$ were also below the threshold value of $1000 \mu \mathrm{S} / \mathrm{cm}$ indicating resistivity but significant anomalies were observed in some samples $(\mathrm{G}, \mathrm{H}$, $\mathrm{J}, \mathrm{M}, \mathrm{O}, \mathrm{X}$ ) with low conductivity values in the range of 202 - 218. According to Atekwana et al., [19], it was observed that hydraulic conductivity in an aquifer contaminated with hydrocarbon is lowered (possibly by the high resistivity property of hydrocarbons) and increases with time as attenuation processes sets in or influx of ionic elements in the environmental media. Inferring, some or all of these stations might have possibly contaminated the water sources around them.

Total dissolved solids (TDS) measured in mg/l across all samples ranged from 94.3 - 565 where $54 \%$ of the samples had values higher than the permissible limit of $500 \mathrm{mg} / \mathrm{l}$. TDS comprises of inorganic substances and small amounts of organic compounds that are dissolved in water [20, 21].

\subsection{Heavy Metals Concentration}

The health risk impacts of heavy metals even at low concentrations make it a required assessment for water quality determination $[22,26,30]$. Hence the exact idea of water quality was determined when concentrations of these elements were compared to the NSDWQ [18].

Across all samples as shown on Table 2, the result revealed that $\mathrm{Pb}, \mathrm{Cd}, \mathrm{Cr}$ and $\mathrm{Ni}$ all had high concentrations when compared to the NSDWQ [18] acceptable limits in some of the samples while $\mathrm{Cu}, \mathrm{Zn}$ and $\mathrm{Fe}$ across all samples had concentration within the National permissible limit for drinking water standard.

Lead $(\mathrm{Pb})$ were undetected in samples E, F, G, H, I, P, Q, $\mathrm{T}, \mathrm{U}, \mathrm{V}$, however, low concentrations the same as the NSDWQ standards $(0.01 \mathrm{mg} / \mathrm{l})$ were detected in samples A, J, $\mathrm{K}, \mathrm{M}, \mathrm{N}, \mathrm{Y}, \mathrm{Z}$ while the higher values $(0.02-0.05 \mathrm{mg} / \mathrm{l})$ were detected in samples B, C, D, L, O, S, W, X. (Figure 7). This observation corroborates the findings by [33] that $\mathrm{Pb}$ concentrations were found in groundwater and could be released into the environment from anthropogenic sources related to handling of petroleum products or mechanic workshops.

Cadmium (Cd) were undetected in samples A, B, D, E, F, G, H, I, K, L, M, O, P, Q, T, U, V, W, X, Y, Z, while the higher concentrations than the NSDQW [18] permissible limit value $(0.003 \mathrm{mg} / \mathrm{l})$ were detected in samples $\mathrm{B}, \mathrm{C}, \mathrm{D}, \mathrm{L}$, $\mathrm{O}, \mathrm{S}, \mathrm{W}, \mathrm{X}$ with values of $0.01 \mathrm{mg} / \mathrm{l}$ (Figure 8 ). In comparison to the study where groundwater quality was also measured at close proximity to petrol stations and mechanic workshops in Calabar metropolis, Nigeria [33], concentrations of $\mathrm{Cd}$ in the present study where detected were also higher than the permissible limits which suggests the identified stations possibly operates a mechanic workshop within its vicinity too as reported that $\mathrm{Cd}$ are associated with batteries [34].

Chromium (Cr) were undetected in samples A, C, G, H, J, $\mathrm{M}, \mathrm{O}, \mathrm{Q}, \mathrm{R}, \mathrm{S}, \mathrm{T}, \mathrm{V}$, however, lower concentrations below and also the same as the NSDWQ standards $(0.05 \mathrm{mg} / \mathrm{l})$ were detected in samples B, E, I, K, L, N, P, U, W, X, Y, Z while the higher values $(0.060 \& 0.075 \mathrm{mg} / \mathrm{l})$ were detected in samples F and D respectively (Figure 9). In comparison to the study where groundwater quality was also measured at close proximity to petrol stations and mechanic workshops in Calabar metropolis, Nigeria [33], concentrations of $\mathrm{Cr}$ in the present study were lower and mostly within the permissible limits. A possible source of $\mathrm{Cr}$ is from anticorrosive chemicals [34].

Nickel (Ni) were undetected in samples D, H, I, L, M, N, $\mathrm{O}, \mathrm{P}, \mathrm{Q}, \mathrm{R}, \mathrm{U}, \mathrm{V}, \mathrm{W}, \mathrm{X}, \mathrm{Z}$ however, lower concentrations and the same as the NSDWQ standards $(0.02 \mathrm{mg} / \mathrm{l})$ were detected in samples $A, B, C, F, G, K, S, T$ while the higher values $(0.025-0.045 \mathrm{mg} / \mathrm{l})$ were detected in samples $\mathrm{E}, \mathrm{J}$ and $\mathrm{Y}$ (Figure 10). The values of $\mathrm{Ni}$ in this study were lower and $88 \%$ fell within the permissible limits unlike when compared to Nganje, Edet \& Ekwere, [33] where all the value were higher than the referenced data.

Although, heavy metals are naturally existing in the earth media but major sources of contaminants are through anthropogenic sources [22]. Sources of the prominent compounds with high concentrations from this study such as $\mathrm{Pb}, \mathrm{Ni}, \mathrm{Cd}$ and $\mathrm{Cr}$ include electroplating industries, detergents and refined petroleum products, metallic materials, automobiles parts, stainless steel, galvanized pipes and piping networks, wastewater etc. [23 -25]. Hence, the introduction of these compounds could be due to leaching, runoffs and underground flow of percolated water from the surrounding stations into the groundwater system.

\subsection{Possible Health Risk from the Pollutants Identified}

The physical parameters mentioned above e.g. turbidity, TDS, TH might not significantly in itself pose a health risk but render the water aesthetically unappealing [18, 27]. Turbidity which is the presence of finely suspended or colloidal particles can inhibit the chemical reaction of treatments on pathogens by shielding them hereby indirectly promoting water-related diseases [21, 28]. Total dissolved 
solid (TDS) are majorly inorganic salts dissolved in water, limited information is available on its possible health effects but considered unappealing to consumers when content is high in drinking water as it influences the odour and taste $[21,29]$. Total hardness- an indication of the presence of magnesium and calcium also poses no health risk normally but could be detrimental for people with kidney diseases [27].

Unlike the physical parameters, the heavy metals found in the samples with high concentrations are majorly toxic elements and poses great health effects even at low concentrations. Lead $(\mathrm{Pb})$ has been reported to cause health defects such as brain damage, cancer, brain tumours, neonatal defects, anaemia, central and peripheral nervous system breakdown [18, 21, 22]. Nickel (Ni) at high concentration can cause DNA damage, decrease body weight, skin eczemas (water-washed infection), and noted as possibly carcinogenic $[21,22,27]$. Cadmium (Cd) is known to cause damage to the kidney, bones in both young and old, also responsible for bronchitis, anaemia [18, 21, 22]. Chromium (Cr) at high level of exposure can damage the liver and kidney, skin ulceration and also affect the central nervous system [21, 22].

\section{Conclusion}

Based on the findings, the low conductivity (high resistivity) characteristics across all samples, with high turbidity, high concentrations of lead, cadmium, chromium, and nickel at significant levels revealed the possibility of groundwater contamination from underground storage tanks and other related activities in these filling stations, which depicts that the untreated continuously use of these water sources and uncontrolled activities of these filling stations poses health risk to the consumers and people around them.

\section{References}

[1] Environment Agency. (2013). Groundwater protection: Principles and practice (GP3).

[2] UNESCO (2007) UNESCO water portal newsletter no 161: water-related disease.

[3] Odukoya, A. M. (2015). Geochemical and quality assessment of groundwater in some Nigerian basement complex. International journal of environmental science and technology, 12 (11), 3643-3656.

[4] Badu, E. (2015). Determination of hydrocarbon contamination of underground water around fuel filling stations in selected residential areas in the Kumasi metropolis in the Ashanti region of Ghana. 107.

[5] Odipe, O. E., Ogunleye, R. A., Sulaiman, M., Abubakar, S. S., \& Olorunfemi, M. O. (2018). Integrated Geophysical and Hydro-chemical Investigations of Impact of the Ijemikin Waste Dump Site in Akure, Southwestern Nigeria, on Groundwater Quality. Journal of Health and Pollution, 8 (18), 180604.

[6] Arokoyu, S. B., Mark, O., \& Jochebed, A. O. (2015). Petrol
Filling Stations' Location and Minimum Environmental Safety Requirements in Obio Akpor LGA, Nigeria. International Journal of Scientific Research and Innovative Technology, 2 (11), 19.

[7] Oloko-Oba, M., Badru, R., Popoola, O. S., Samson, S. A., Alaga, T. A., \& Ogunyemi, S. A. (2016). Assessment of Filling Station in Ilorin, Kwara State, Nigeria Using Geospatial Techniques. International Journal of Scientific Research in Computer Science, Engineering and Information Technology, $1(2), 7$.

[8] Olukoya, E. O., Ana, G. R. E. E., \& Oloruntoba, E. O. (2016). Assessment of Soil Contamination with Monocyclic Aromatic Hydrocarbons and Heavy Metals in Residential Areas Sited Close to Fuel Filling Stations in Ibadan Metropolis. Journal of Environment Pollution and Human Health, 4 (3), 60-65. https://doi.org/10.12691/jephh-4-3-1.

[9] Odipe, O., Lawal, A., Adio, Z., Karani, G., \& Sawyerr, H. (2018). GIS-Based Location Analyse of Retail Petrol Stations in Ilorin, Kwara State, Nigeria. International Journal of Scientific \& Engineering Research, 9 (12), 790-794.

[10] Lu, S. J., Wang, H. Q., \& Yao, Z. H. (2006). Isolation and characterization of gasoline-degrading bacteria from gas station leaking-contaminated soils. Journal of Environmental Sciences, 18 (5), 969-972.

[11] do Rego, E. C. P. \& Netto, A. D. P. "PAHs and BTEX in groundwater of gasoline stations from Rio de Janeiro City, Brazil". Bulletin of environmental contamination and toxicology, 79 (6), 660-664, 2007.

[12] Samuel, J. A. "Spatial Location of Filling stations in Kaduna. Kaduna" 2011: Scribid Inc.

[13] Club, S. (2011). Leaking underground storage tanks: A threat to public health \& environment. San Francisco.

[14] Rosales R M, Martínez-Pagán P, Faz A and Bech J 2014 J. Geochem. Explor. 147 306-20.

[15] Ramalho A. M. Z., de Aquino Sobrinho H. L., dos Anjos H. L, de Castro Dantas T. N., \& da Silva D. R, "Study of contamination by benzene due to diesel and gasoline leaks at a gas station in Natal/Brazil". Int J Eng Technol, 14 (2), 49-54, 2014.

[16] Rao, S. M., Joshua, R. E., \& Arkenadan, L. (2017). BTEX contamination of Bengaluru aquifers, Karnataka, India. Journal of Environmental Engineering and Science, 12 (3), 56-61.

[17] Chen X H, Yang Q, Sun C J. Kang L J, Zhao Z and Chen M M (2013) Res. Environ. Sci. 26 1171-7.

[18] Nigerian Standard for Drinking Water Quality (NSDQW). 2007. Nigerian Industrial Standard NIS 554, Standard Organization of Nigeria: Lagos, Nigeria.

[19] Atekwana, E. A., Atekwana, E. A., Rowe, R. S., Werkema Jr, D. D., \& Legall, F. D. (2004). The relationship of total dissolved solids measurements to bulk electrical conductivity in an aquifer contaminated with hydrocarbon. Journal of Applied Geophysics, 56 (4), 281-294.

[20] Olajire, AA. and Imeppeoria, FE. 2001. Water quality assessment of Osun River: Studies on inorganic nutrients. Environmental Monitoring Assessment, 69: 17-28. 
[21] WHO (2006). Guidelines for Drinking-Water Quality. Third edition incorporating first addendum. Vol. 1, Recommendations (electronic resource). Geneva: WHO. www.who.int/water_sanitation_health/dwq/guidelines/en.

[22] Gautam, S. K., Maharana, C., Sharma, D., Singh, A. K., Tripathi, J. K., Singh, S. K., (2015). Evaluation of groundwater quality in the Chotanagpur Plateau region of the Subarnarekha River Basin, Jharkhand state, India. Sustain. Water Qual. Ecol. 6, 57-74.

[23] JECFA (2000) Summary and conclusions of the fifty-fifth meeting, Geneva, 6-15 June 2000. Geneva, World Health Organization, Joint FAO/WHO Expert Committee on Food Additives.

[24] WHO (2003a) Lead in drinking-water. Background document for preparation of WHO Guidelines for drinking-water quality. Geneva, World Health Organization (WHO/SDE/WSH/03.04/9).

[25] WHO (2003b) Cadmium in drinking-water. Background document for preparation of WHO Guidelines for drinkingwater quality. Geneva, World Health Organization (WHO/SDE/WSH/03.04/80).

[26] Raimi, M., Nimisngha, D., Odipe, O. E., \& Olalekan, A. S. (2018). Health Risk Assessment on Heavy Metals Ingestion through Groundwater Drinking Pathway for Residents in an Oil and Gas Producing Area of Rivers State, Nigeria. Open Journal of Yangtze Oil and Gas, 3, 191-206.
[27] Kolawole, O. M., \& Afolayan, O. (2017). Assessment of groundwater quality in Ilorin, north central Nigeria. Arid Zone Journal of Engineering, Technology and Environment, 13 (1), 111-126.

[28] Okpokwasili, G. C., Douglas, S. I., \& Inengite, A. K. (2013). Seasonal variations of some physicochemical parameters of groundwater in crude oil flow stations. Journal of Environment, Science and Water Resources, 2 (1), 22-26.

[29] Aydin, A. (2007). The Microbiological and Physico-Chemical Quality of Groundwater in West Thrace, Turkey. Polish journal of environmental studies, 16 (3).

[30] Patil, P. N., Sawant, D. V., \& Deshmukh, R. N. (2012). Physico-chemical parameters for testing of water-A review. International Journal of Environmental Sciences, 3 (3), 1194.

[31] APHA (1998) Standard Methods for the Examination of Waste Water. 20th Edition, APHA Inc., New York, 2-134.

[32] AOAC (2005) Official methods of analysis, 18th edn. Association of Official Analytical Chemists, Washington DC.

[33] Nganje, T. N., Edet, A. E., \& Ekwere, S. J. (2007). Concentrations of heavy metals and hydrocarbons in groundwater near petrol stations and mechanic workshops in Calabar metropolis, southeastern Nigeria. Environmental Geosciences, 14 (1), 15-29.

[34] Merian, E., 1991, Metals and their compounds in the environment: Occurrence, analysis and biological relevance: Weinheim, Ger-many, VCH Publishers, 1438 p. 